\title{
Progress bias versus status quo bias in the ethics of emerging science and technology
}

\section{Bjørn Hofmann ${ }^{1,2}$}

1 Department of Health Sciences, Norwegian University of Science and Technology, Gjøvik, Norway 2 Centre of Medical Ethics, University of Oslo, Oslo, Norway

\section{Corresponding Author: Bjørn Hofmann}

Centre for Medical Ethics

University of Oslo

PO Box 1130, Blindern

N-0318 Oslo, Norway

Email: b.m.hofmann@medisin.uio.no

Bjørn Hofmann is full professor at The Norwegian University of Science and Technology at Gjøvik and an adjunct professor at the Center for Medical Ethics at the University of Oslo. Hofmann's research and teaching covers five main areas: 1 . Philosophy of medicine, 2. (Bio)medical ethics, 3. Ethics in health technology assessment, 4. Philosophy of health sciences and technology, and 5. Research ethics and Research Integrity.

Abstract: How should we handle ethical issues with emerging science and technology in a rational way? This is a crucial issue in our time. On the one hand there is great optimism with respect to technology. On the other, there is skepticism and pessimism. As both perspectives are based on scarce evidence, they may appear speculative and irrational. Against the pessimistic perspective to emerging technology it has been forcefully argued that there is a status quo bias (SQB) fueling irrational attitudes to emergent science and technology greatly hampering useful development and implementation. Therefore, this article starts by analyzing the SQB using human enhancement as a case. It reveals that SQB may not be as prominent in restricting the implementation of emergent technologies as claimed in the ethics literature because a) SQB is fueled by other and less relevant drivers than addressed in the literature and $b$ ) that it is at best one amongst many drivers of 
attitudes towards emergent science and technology, and c) that SQB may not be a particularly prominent driver of irrational decision making. While recognizing that SQB can be one driver behind pessimism, the article investigates other and countering forces which may be as forceful as SQB. Progress bias is suggested as a generic term for the various drivers of unwarranted science and technology optimism. Based on this analysis a test for avoiding or reducing this progress bias is proposed. Accordingly, we should recognize and avoid a broad range of biases in the assessment of emerging and existing science and technology in order to promote an open and transparent deliberation.

Key words: status quo bias, psychology, attitudes, optimism, pessimism, skepticism

\section{Background}

Modern science and technology pose profound ethical challenges, especially as they make it possible to change the human being in constitutive ways. Gene editing, gene drives, and synthetic gemmate production are but few examples. How we target such major issues appears to vary greatly, and tend to depend on our basic perspectives: Where some are optimistic others are pessimists, ${ }^{1}$ where some find technological innovations attractive, others find them aversive. ${ }^{2}$ Where technological optimists in general think that innovations lead to more benefits than harms and risks, pessimists think it is the other way around. Both camps can find support in the philosophical literature. Spengler, ${ }^{3}$ Nietzsche, ${ }^{4}$ Heidegger, ${ }^{5}$ Adorno, ${ }^{6}$ Foucault, ${ }^{7}$ and many others ${ }^{8}$ are often interpreted as and have inspired

\footnotetext{
${ }^{1}$ Postrel, V. (2011). The Future and Its Enemies: The Growing Conflict Over Creativity, Enterprise. New York: Simon and Schuster.

${ }^{2}$ Hochschild, J., \& Sen, M. (2015). Technology optimism or pessimism about genomic science: variation among experts and scholarly disciplines. The ANNALS of the American Academy of Political and Social Science. 658(1), 236-252.

${ }^{3}$ Spengler, O. (1991). The decline of the West. Oxford: Oxford Paperbacks; Spengler, O. (2015). Man and technics: A contribution to a philosophy of life. London: Arktos.

${ }^{4}$ Kroker, A. (2004). The will to technology and the culture of nihilism: Heidegger, Nietzsche and Marx. Toronto: University of Toronto Press.

${ }^{5}$ Heidegger, M. (1977). The question concerning technology, and other essays (W. Lovitt, Trans.). New York: Harper \& Row; Ihde, D. (2010). Heidegger's technologies: Postphenomenological perspectives. New York: Fordham Univ Press; Matthewman, S. (2013). Michel Foucault, technology, and actor-network theory. Techné: Research in Philosophy and Technology. 17(2), 274-292.
} 
technology pessimists. On the other hand, and often well situated in the tradition from the

Enlightenment, ${ }^{9}$ scientific progress and new technologies are encountered and implemented with great optimism. Emergent technologies are frequently met with hype, hope, and hubris. ${ }^{10}$ Interestingly, technological optimism and pessimism tend to vary with time, culture, ${ }^{11}$ and technology. ${ }^{12}$ At present, technological optimism is especially outspoken in fields such as artificial intelligence (AI), BigData, gene editing, and synthetic biology.

One crucial challenge with these perspectives is the lack of evidence. For many of the emerging technologies we lack knowledge of their benefits, harms, and their transformative or disruptive effects. These epistemic shortcomings make both the technology optimists and pessimists quite speculative and irrational.

Traditionally, technological optimism and pessimism have been studied in terms of general attitudes towards technologies, ${ }^{13}$ trust, ${ }^{14}$ specific drivers, ${ }^{15}$ and in terms of narratives and -isms, such as determinism and productivism. ${ }^{16}$ However, they have less often been analyzed in terms of irrational

\footnotetext{
${ }^{6}$ Krakauer, E. (1998). The disposition of the subject: reading Adorno's dialectic of technology. Evanston, III. : Northwestern University Press

${ }^{7}$ Foucault, M., Davidson, A. I., \& Burchell, G. (2008). The birth of biopolitics: lectures at the Collège de France, 1978-1979. New York: Springer.

${ }^{8}$ Gadamer, H.-G., \& Brotz, H. (1977). Theory, technology, practice: the task of the science of man. Social research, 529-561; Jonas, H. (1985). The imperative of responsibility: In search of an ethics for the technological age. Chicago: University of Chicago press; Marx, L. (1994). The idea of "technology" and postmodern pessimism Technology, pessimism, and postmodernism (pp. 11-28). New York: Springer.

${ }_{9}^{9}$ Pinker, S. (2018). Enlightenment Now: The Case for Reason, Science, Humanism, and Progress. New York: Penguin.

${ }^{10}$ Caulfield, T. (2004). Biotechnology and the popular press: Hype and the selling of science. Trends in Biotechnology, 22(7), 337-339; Caulfield, T., \& Condit, C. (2012). Science and the sources of hype. Public Health Genomics, 15(3-4), 209-217.

${ }^{11}$ Allum, N., Sturgis, P., Tabourazi, D., \& Brunton-Smith, I. (2008). Science knowledge and attitudes across cultures: A meta-analysis. Public understanding of science, 17(1), 35-54.

${ }^{12}$ Hochschild \& Sen, op. cit. note 2.

${ }^{13}$ Kerschner, C., \& Ehlers, M.-H. (2016). A framework of attitudes towards technology in theory and practice. Ecological Economics, 126, 139-151. doi:https://doi.org/10.1016/j.ecolecon.2016.02.010

${ }^{14}$ Hochschild, J., Crabill, A., \& Sen, M. (2012). Technology optimism or pessimism: how trust in science shapes policy attitudes toward genomic science. Issue in Technology Innovation at Brookings, 21.

${ }^{15}$ Hofmann, B. M. (2015). Too much technology. BMJ, 350, h705. doi:10.1136/bmj.h705

${ }^{16}$ Strand, R., Saltelli, A., Giampietro, M., Rommetveit, K., \& Funtowicz, S. (2016). New narratives for innovation. Journal of Cleaner Production, 197: 1849-1853.
} 
aspects, such as cognitive or emotional mechanisms or biases. While a wide range of biases have been identified in psychology and economics, ${ }^{17}$ they have not been extensively applied to study how established and emerging technologies are assessed and implemented.

One highly interesting exception is where technology pessimism is explained as a result of the status quo bias (SQB). SQB is defined as a cognitive bias which describes the irrational preference for an option only because it preserves the current state of affairs. ${ }^{18}$ Accordingly, this article takes the SQB as a point of departure to discuss attitudes to science and technology ${ }^{19}$, such as technology pessimism. While SQB has been studied in $\mathrm{GMOs},{ }^{20}$ information systems, ${ }^{21}$ and nano-technology, ${ }^{22}$ this article will use human enhancement as its main example $e^{23}$ but also refer to other technologies. The objective of this study is to investigate biases and irrational psychological mechanisms that influence our assessment of emerging technologies. The study starts to scrutinize the claim that SQB muddles our decisions on technologies, such as human enhancement. It reveals that there is weak evidence for the SQB playing a major role in the assessment of emergent technologies, such as human enhancement technologies. Other mechanisms than the endowment effect, purportedly explaining SQB, seem to do a better job. It seems that SQB is not a particularly prominent driver of irrational implementation of technology and driving technology pessimism. Other drivers may be as forceful as SQB, and work in the opposite direction, i.e., to reinforce technology optimism. Progress bias is suggested as a generic term for the various biases and forces fueling unwarranted science and

\footnotetext{
${ }^{17}$ Haselton, M. G., Nettle, D., \& Murray, D. R. (2015). The evolution of cognitive bias. The handbook of evolutionary psychology. (pp. 1-20) New York: Wiley; Mata, R. (2012). Cognitive bias. Encyclopedia of human behaviour, 1, 531-535.

${ }^{18}$ Kahneman, D., \& Tversky, A. (2013). Choices, values, and frames. HANDBOOK OF THE FUNDAMENTALS OF FINANCIAL DECISION MAKING: Part I: World Scientific, pp. 269-278.

${ }^{19}$ There are of course important differences between science and technology. However, as many of these may not be very important for the topic of this article, I will not distinguish between them here.

${ }^{20}$ Fox, J. A., Hayes, D. J., \& Shogren, J. F. (2002). Consumer preferences for food irradiation: How favorable and unfavorable descriptions affect preferences for irradiated pork in experimental auctions. Journal of risk and Uncertainty, 24(1), 75-95.

${ }^{21}$ Kim, H.-W., \& Kankanhalli, A. (2009). Investigating user resistance to information systems implementation: A status quo bias perspective. MIS quarterly, 567-582.

${ }^{22}$ Nordmann, A. (2007). If and then: a critique of speculative nanoethics. Nanoethics, 1(1), 31-46.

${ }^{23}$ Bostrom, N., \& Ord, T. (2005). Status Quo Bias in Bioethics: The Case for Cognitive Enhancement: Improving Humans. Oxford: Oxford University Press.
} 
technology optimism. Based on this analysis a test for avoiding or reducing this progress bias is developed. The conclusion is that we should focus on a broader range of drivers than only single biases, such as SQB, when assessing attitudes driving irrational or unreasoned assessments of technology.

\section{Technology pessimism and the SQB}

Let us start with investigating SQB. The SQB was introduced in decision analysis ${ }^{24}$ and has more recently been used to explain reactions to and irrational assessments of innovations in science and technology. In a seminal article Nick Bostrom and Toby Ord argued that SQB is a prevalent cognitive bias in judgements about emerging technologies, such as human enhancement technologies. ${ }^{25} \mathrm{By}$ removing the bias, Bostrom and Ord argue, the demurrals against enhancement technologies will disappear. Objections will be revealed to be "extremely implausible" and it will become clear that "the case for developing and using genetic cognitive enhancements is much stronger than commonly realized". ${ }^{26}$

Bostrom and Ord define SQB "as an inappropriate (irrational) preference for an option because it preserves the status quo." They find the "psychological evidence of status quo bias" in the so-called endowment effect, i.e., that people ascribe more value to things merely because they have or own them. In order to illustrate their point, Bostrom and Ord refer to examples and experiments, such as "The Mug Experiment," "Hypothetical Choice Tasks," and the "Electric Power Consumers." For example, the Mug Experiment shows that people tend to cling to their awards (such as mugs or chocolate bars) even when they are offered to exchange them at very favourable conditions.

\footnotetext{
${ }^{24}$ Kahneman, D., Knetsch, J. L., \& Thaler, R. H. (1991). Anomalies: The endowment effect, loss aversion, and status quo bias. Journal of Economic perspectives, 5(1), 193-206; Owen, G. (2014). Moral enhancement and moral disagreement. (PhD), University of Oxford; Samuelson, W., \& Zeckhauser, R. (1988). Status quo bias in decision making. Journal of risk and uncertainty, 1(1), 7-59.

${ }^{25}$ Bostrom, N., \& Ord, T. (2006). The reversal test: eliminating status quo bias in applied ethics. Ethics, 116(4), 656-679.

${ }^{26}$ Bostrom \& Ord, op. cit. note 25.
} 
Only one example from health care is presented, i.e., "the Asian disease problem," which is about the choice between alternative programs to combat "the Asian disease." Both programs have identical outcomes, but are framed differently. Studies show that there is a clear preferences for alternatives presented as gains over those presented as losses. ${ }^{27}$

Bostrom and Ord take these examples as proofs of the SQB. Moreover, they argue that revealing and undermining biases is an important task for ethics: "Recognizing and removing a powerful bias will sometimes do more to improve our judgments than accumulating or analyzing a large body of particular facts. In this way, applied ethics could benefit from incorporating more empirical information from psychology and the social sciences about common human biases." ${ }^{28}$ Hence, by busting the status quo bias, we will have a much more balanced assessment of technologies, such as cognitive enhancement technologies.

In order to reveal and avoid SQB, they suggest a test:

"(REVERSAL TEST) When a proposal to change a certain parameter is thought to have bad overall consequences, consider a change to the same parameter in the opposite direction. If this is also thought to have bad overall consequences, then the onus is on those who reach these conclusions to explain why our position is such that it cannot be improved through changes to this parameter. ${ }^{\prime 29}$

This heuristic is further strengthened by a "Double Reversal Test:"
"Suppose it is thought that increasing a certain parameter and decreasing it would both have bad overall consequences. Consider a scenario in which a natural factor threatens to move the parameter in one direction and ask whether it would be good to counterbalance this change by an intervention to preserve the status quo. If so, consider a later time when the

\footnotetext{
${ }^{27}$ It may of course be argued that neither gain nor loss fall under their definition of the SQB as both represent changes instead of preserving status quo.

${ }^{28}$ Bostrom \& Ord, op. cit. note 25.

${ }^{29}$ Bostrom \& Ord, op. cit. note 23.
} 
naturally occurring factor is about to vanish and ask whether it would be a good idea to intervene to reverse the first intervention. If not, then there is a strong prima facie case for thinking that it would be good to make the first intervention even in the absence of the natural countervailing factor." ${ }^{30}$

\section{The status of SQB in the assessment of emergent bio-technologies}

How important, then, is the status quo bias in the assessments and deliberation on emerging technologies, such as human enhancement technologies?

Surely, the status quo bias has been used as a tentative explanation for the differences in users' and non-users' attitudes toward pharmaceutical cognitive enhancement. ${ }^{31}$ Moreover, optimistic predictions of novel biotechnologies have largely not been fulfilled as progress has been much slower than initially anticipated. ${ }^{32}$ This may of course be due to status quo bias. However, beyond such specific references there are no systematic reviews or meta-analysis supporting the presence of the status quo bias (based on the endowment effect) in the assessment of emergent technologies. One may also be baffled by the fact that so few examples of SQB are provided from studies of enhancement technologies, given all the ample attitude surveys with respect to new biotechnologies. ${ }^{33}$ Accordingly, it has been argued that SQB and the corresponding heuristic tests have limited applications. ${ }^{34}$

Contrary to how trenchantly partisan the lay people's view on new biotechnologies in general, and human enhancement technologies in particular, are thought to be, it has been shown that "the

\footnotetext{
${ }^{30}$ Bostrom \& Ord, op. cit. note 23.

${ }^{31}$ Schelle, K. J., Faulmüller, N., Caviola, L., \& Hewstone, M. (2014). Attitudes toward pharmacological cognitive enhancement-a review. Front Syst Neurosci. 8, 53.

${ }^{32}$ Betz, U. A. K. (2018). Is the force awakening? Technological forecasting and social change. 128, 296-303. doi:https://doi.org/10.1016/j.techfore.2017.08.006

${ }^{33}$ Fitz, N. S., Nadler, R., Manogaran, P., Chong, E. W., \& Reiner, P. B. (2014). Public attitudes toward cognitive enhancement. Neuroethics. 7(2), 173-188; Gaskell, G., Allansdottir, A., Allum, N., Castro, P., Esmer, Y., Fischler, C., . . . Mejlgaard, N. (2011). The 2010 Eurobarometer on the life sciences. Nature biotechnology. 29(2), 113; Gaskell, G., Allum, N., Bauer, M., Durant, J., Allansdottir, A., Bonfadelli, H., . . Gutteling, J. M. (2000). Biotechnology and the European public. Nature biotechnology. 18(9), 935.

${ }^{34}$ Agar, N. (2010). Humanity's end: why we should reject radical enhancement. Boston: MIT Press.
} 
public is responsive to salient moral reasons ${ }^{\prime 35}$ and not hampered by SQB. On contrary different note, it may be argued that the SQB is hampering progress, not only in impeding the implementation of new and emergent technologies, but also in barring important disinvestment of low, no, and negative value technologies. ${ }^{36}$

\section{SQB beyond the endowment effect}

One reason for the lack of empirical evidence for the SQB may be that it is studied and explained in terms of the wrong psychological effect. It may for example be that the endowment effect expresses an emotional attachment to specific items (ownership) and that it is only loosely related to SQB, or that there are other mechanisms that may describe SQB much better than the endowment effect. Hence, the status quo bias may not only be based on the endowment effect as Bostrom and Ord explicate. In fact, the SQB can be explained by a number of other non-rational mechanisms, such as loss aversion, regret avoidance, repeated exposure, rationalization, and a simple assumption of goodness due to mere existence and longevity. ${ }^{37}$

Other relevant psychological effects are biases in information processing, for example by inflating assessments of risks, ${ }^{38}$ or that certain facts are settled in cultural and political meanings, where attitudes toward technologies serve as a marker for membership in specific (political and/or cultural) identity groups. ${ }^{39}$ To change one's mind and attitude about technology may be conceived of as a

\footnotetext{
${ }^{35}$ Fitz et al., op. cit. Note 33.

${ }^{36}$ Scott, I. A., Soon, J., Elshaug, A. G., \& Lindner, R. (2017). Countering cognitive biases in minimising low value care. Med J Aust. 206(9), 407-411.

${ }^{37}$ Eidelman, S., \& Crandall, C. S. (2012). Bias in favor of the status quo. Social and Personality Psychology Compass. 6(3), 270-281.

${ }^{38}$ Bolsen, T., Druckman, J. N., \& Cook, F. L. (2014). The influence of partisan motivated reasoning on public opinion. Political Behavior. 36(2), 235-262; Kahan, D. (2015). What is the'Science of Science Communication'? Journal of Science Communication. 14(3), 1-10; Taber, C. S., \& Lodge, M. (2006). Motivated skepticism in the evaluation of political beliefs. American Journal of Political Science. 50(3), 755-769.

${ }^{39}$ Druckman, J. N., \& Bolsen, T. (2011). Framing, motivated reasoning, and opinions about emergent technologies. Journal of Communication. 61(4), 659-688; Kahan, D. M., Braman, D., Cohen, G. L., Gastil, J., \& Slovic, P. (2010). Who fears the HPV vaccine, who doesn't, and why? An experimental study of the mechanisms of cultural cognition. Law and human behavior. 34(6), 501-516.
} 
threat to certain aspects of one's world view ${ }^{40}$ or social identity. ${ }^{41}$ To alter attitudes toward technologies is like changing favorite football (or baseball) team.

It has been shown that our tendency of coming to conclusions that are congruent with our identity can bias our information processing, even when this comes at the cost of accuracy. ${ }^{42}$ Moreover, identity-protective cognition can make us believe that empirical evidence supports the opposite conclusion of what is generally held. ${ }^{43}$ In fact, this can explain why conceptions tend to become polarized, and why this polarization may be strongest among those who are most informed and possess the greatest cognitive capacities. ${ }^{44}$ Increased evidence may do little in making people change their opinions. ${ }^{45}$ Moreover, politicizing issues may also have a strong biasing effect, sometimes associated with SQB. ${ }^{46}$ Exposure to messages that produce anxiety may also trigger cognitive biases relevant in the assessment of technologies. ${ }^{47}$ Moreover, negative attitudes towards various technologies may also be related to the unfamiliarity of devices and technologies, previously called "the walkman effect." ${ }^{48}$

\footnotetext{
${ }^{40}$ Lewandowsky, S., \& Oberauer, K. (2016). Motivated rejection of science. Current Directions in Psychological Science. 25(4), 217-222.

${ }^{41}$ Sherman, D. K., \& Cohen, G. L. (2002). Accepting threatening information: Self-Affirmation and the reduction of defensive biases. Current Directions in Psychological Science. 11(4), 119-123; Sherman, D. K., \& Cohen, G. L. (2006). The psychology of self-defense: Self-affirmation theory. Advances in experimental social psychology. 38, 183-242.

42 Dawson, E., Gilovich, T., \& Regan, D. T. (2002). Motivated Reasoning and Performance on the was on Selection Task. Personality and Social Psychology Bulletin, 28(10), 1379-1387; Taber \& Lodge, op.cit. note 38.

${ }^{43}$ Kahan, D. M., Peters, E., Dawson, E. C., \& Slovic, P. (2017). Motivated numeracy and enlightened selfgovernment. Behavioural Public Policy, 1(1), 54-86.

${ }^{44}$ Hart, P. S., \& Nisbet, E. C. (2012). Boomerang effects in science communication: How motivated reasoning and identity cues amplify opinion polarization about climate mitigation policies. Communication Research. 39(6), 701-723; Kahan, D. M., Peters, E., Wittlin, M., Slovic, P., Ouellette, L. L., Braman, D., \& Mandel, G. (2012). The polarizing impact of science literacy and numeracy on perceived climate change risks. Nature climate change. 2(10), 732; Taber \& Lodge, op.cit. note 38.

${ }^{45}$ Nyhan, B., \& Reifler, J. (2015). Does correcting myths about the flu vaccine work? An experimental evaluation of the effects of corrective information. Vaccine. 33(3), 459-464. doi:10.1016/j.vaccine.2014.11.017 Nyhan, B., Reifler, J., Richey, S., \& Freed, G. L. (2014). Effective messages in vaccine promotion: a randomized trial. Pediatrics. 133(4), e835-842. doi:10.1542/peds.2013-2365.

${ }^{46}$ Bolsen, T., \& Druckman, J. N. (2015). Counteracting the politicization of science. Journal of Communication, 65(5), 745-769; Bolsen, T., Druckman, J. N., \& Cook, F. L. (2014). How frames can undermine support for scientific adaptations: Politicization and the status-quo bias. Public Opinion Quarterly. 78(1), 1-26.

${ }^{47}$ Arceneaux, K. (2012). Cognitive biases and the strength of political arguments. American Journal of Political Science. 56(2), 271-285.

${ }^{48}$ Hosokawa, S. (1984). The walkman effect. Popular music. 4, 165-180.
} 
It may of course also be that the SQB is an expression of and an explanation for a deeply felt frustration amongst transhumanists with "naysaying sceptics" and living dead "zombies," not believing that they can live beyond 100, passively accepting their wretched future; and always thinking that radical change will be negative. These sceptics are characterized as "suicide bombers trying to manufacture a climate of terror in humanity's existential horizons. ${ }^{\prime 49}$ John Harris expresses this in another way, illustrating how one should be critical of sceptics: «Inevitably, I have found myself criticising the plethora of bad arguments that are always advanced as obstacles to change. This is not, I believe, because I am a natural radical, but rather because I am a natural sceptic. I have found that all too many people are like the mother who said to her daughter 'go and see what your little brother is doing and tell him to stop!' When I go and see what the scientists are doing, I usually find that they are doing a good job and that we should remove rather than increase obstacles in the way of their progress. $\nu^{50}$ Hence, the SQB may be a more overall reaction to skepticism in general, concurring with a general "fear for progress" as described in Steven Pinker's latest book

\section{Enlightenment Now. ${ }^{51}$}

Hence, there seem to be many other psychological mechanisms explaining the SQB. Figure 1 provides an overview over some of them in addition to the endowment effect.

Figure 1 Overview over the relationship between attitudes, biases, and mechanisms with the status quo bias as an example including various types of its driving mechanisms

\footnotetext{
${ }^{49}$ Fuller, S. (2018). We May Look Crazy to Them, But They Look Like Zombies to Us: Transhumanism as a Political Challenge. Fuller, Steve. "We may look crazy to them, but they look like Zombies to us: Transhumanism as a political challenge." Institute for Ethics and Emerging Technologies. http://ieet.org/index.php/IEET/more/fuller20150909

${ }^{50}$ Harris, J. (2015). What is it to do good medical ethics? Journal of Medical Ethics. 41(1), 37-39.

${ }^{51}$ Pinker, op.cit. note 9.
} 


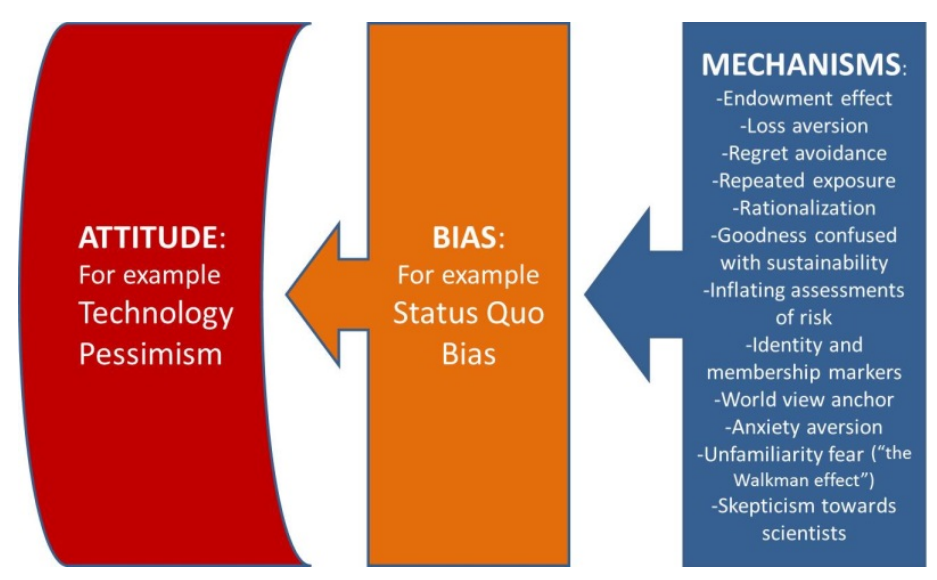

In sum so far, there is poor evidence for the SQB playing a major role in the assessment of emergent technologies, such as human enhancement technologies, especially based on the endowment effect. This is of course not a reason to dismiss SQB in this field. SQB has good evidence in other fields, such as in business and power plant deliberation. ${ }^{52}$ Moreover, explaining and studying SQB in terms of other mechanisms and in other expression may make such analyses valuable. In particular, looking closer at other than the endowment effect, may provide better support for the hypothesis of SQB in the assessment and debates on emergent technologies. Hence, it may well be that SQB is one driver behind science and technology pessimism. The analysis so far, especially the finding that SQB may be part of a polarized game, indicates that there may be other biases spurring attitudes to technology not only towards pessimism. To balance the game, let me now scrutinize some biases promoting science and technology optimism. What are the drivers of optimism, corresponding to SQB driving skepticism?

\section{Technology optimism}

Counter to the resistance and pessimism spurred by SQB, there appears to be a significant optimism with regards to scientific and technological progress. The following is not meant to be a systematic review of science and technology optimism and its mechanisms. It is a selective overview of relevant

\footnotetext{
${ }^{52}$ Bolsen et al., op.cit. note 46.
} 
effects opposing SQB. The point is not to undermine the relevance of SQB, but to balance the picture by illustrating that there are other biases and mechanisms at play that may be as, or even more important than SQB, and which have to be taken into account in the assessment and implementation of emerging science and technology. Hence, we need to view the SQB in context.

One seminal expression of an optimism for science and technology opposing SQB is the law of accelerating returns predicting that paradigm shifts have been and will continue to become increasingly common, leading to "technological change so rapid and profound it represents a rupture in the fabric of human history" (Kurzweil, 2004). ${ }^{53}$ Despite questionable evidence, ${ }^{54}$ the belief in and the promotion of the disruptive character of science and technology has significant clout. ${ }^{55}$ This general optimistic attitude can also be identified in experts in foresights, who tend to be struck by what has been characterized as "over-optimism". ${ }^{56}$ This optimism can also be connected to John Meynard Keynes' conception of animal spirits: “Even apart from the instability due to speculation, there is the instability due to the characteristic of human nature that a large proportion of our positive activities depend on spontaneous optimism rather than mathematical expectations, whether moral or hedonistic or economic. Most, probably, of our decisions to do something positive, the full consequences of which will be drawn out over many days to come, can only be taken as the result of animal spirits-a spontaneous urge to action rather than inaction, and not as the outcome of a weighted average of quantitative benefits multiplied by quantitative probabilities." ${ }^{57}$

\footnotetext{
${ }^{53}$ Kurzweil, R. (2004). The law of accelerating returns. In T. C. (Ed.), Alan Turing: Life and legacy of a great thinker (pp. 381-416). Heidelberg: Springer.

${ }^{54}$ Agar, op.cit. note 34.

${ }^{55}$ Flores, M., Glusman, G., Brogaard, K., Price, N. D., \& Hood, L. (2013). P4 medicine: how systems medicine will transform the healthcare sector and society. Per Med. 10(6), 565-576. doi:10.2217/pme.13.57; Hood, L. (2015). The wellness revolution. Policy: A Journal of Public Policy and Ideas. 31(3), 3; Hood, L., \& Friend, S. H. (2011). Predictive, personalized, preventive, participatory (P4) cancer medicine. Nat Rev Clin Oncol. 8(3), 184-187; Hood, L., Lovejoy, J. C., \& Price, N. D. (2015). Integrating big data and actionable health coaching to optimize wellness. BMC Med. 13(1), 4; Topol, E. (2012). The Creative Destruction of Medicine: How the Digital Revolution Will Create Better Health Care. New York: Basic Books.

${ }^{56}$ Tichy, G. (2004). The over-optimism among experts in assessment and foresight. Technological forecasting and social change. 71(4), 341-363.

${ }^{57}$ Keynes, J. M. (1936). The General Theory of Employment Interest and Money. London: Macmillan and Company.
} 
Such unbridled optimism can be found in many fields ${ }^{58} \mathrm{~A}$ high proportion of the North-American population "[b]elive that modern medicine can cure almost any illness for people who have access to the most advanced technologies and treatments. ${ }^{159}$ They also overestimate benefits and underestimate harms of low-value care.$^{60}$ This can be related to what the innovation scientist Everett Rogers in the 1960s called "pro-innovation bias," considering anything new inherently better than anything already in use. ${ }^{61}$ This again is closely connected to basic argument structures, such as argumentatum ad novitatem, but also to other biases. Trisha Greenhalgh has identified a range of biases in the assessment and implementation of health technologies. ${ }^{62}$ In addition to pro-innovation bias, she mentions subjunctivisation bias, bells and whistles bias, and connectivity bias.

Subjunctivisation bias refers to the fact that much of the policy rhetoric on new technologies rests on optimistic guesses about what they would, could, or may achieve, and not on what they have been shown to achieve in practice. In the absence of technical, regulatory or operational barriers, such technologies tend to be implemented. While the bells and whistles bias assumes that the more functions a technology offers, the better it will work, the connectivity bias presumes that the more technologies and systems to which a new technology can connect, the more useful it will be. The human substitution bias assumes that a technology is as good as, or better than, a human, whatever the task may be. ${ }^{63}$

Corresponding to optimism on benefits, there is evidence that harms of medical interventions are systematically underestimated in clinical research ${ }^{64}$ Numerous factors-conceptual, methodological, and social-contribute to this underestimation. ${ }^{65}$ One important aspect is richly illustrated in Jacob

\footnotetext{
${ }^{58}$ Brownlee, S. (2007). Overtreated: why too much medicine is making us sicker and poorer. New York: Bloomsbury.

${ }^{59}$ Kim, M., Blendon, R. J., \& Benson, J. M. (2001). How interested are Americans in new medical technologies? A multicountry comparison. Health Affairs. 20(5), 194-201.

${ }^{60}$ Schlesinger, M., \& Grob, R. (2017). Treating, Fast and Slow: Americans' Understanding of and Responses to Low-Value Care. The Milbank Quarterly. 95(1), 70-116.

${ }^{61}$ Rogers, E. M. (2010). Diffusion of innovations. New York: Simon and Schuster.

${ }^{62}$ Greenhalgh, T. (2013). Five biases of new technologies. Br J Gen Pract. 63(613), 425-425.

${ }^{63}$ Greenhalgh, op.cit. note 62.

${ }^{64}$ Stegenga, J. (2018). Medical Nihilism. Oxford: Oxford University Press.

${ }^{65}$ Stegenga, J. (2016). Hollow Hunt for Harms. Perspectives on Science. 24(5), 481-504.
} 
Stegenga's book, Medical nihilism, where the malleability of scientific research methods and medical facts is demonstrated by the way that research results strongly depend on how benefits and harms are defined and measured. For example, the vast majority of results from phase-I-trials (who are designed to reveal harms) are rarely published. ${ }^{66}$ Moreover, in documenting outcomes of technologies, benefits tend to be well framed and reported, while harms are downplayed or ignored. $^{67}$

One of the reason for the overestimating of outcomes is connected to the methods of measuring the effectiveness of medical interventions which systematically overestimate benefits: "There are very few cures in medicine, and yet a large proportion of people think that almost any illness can be cured by available interventions.. ${ }^{\prime 68}$ The choice of measuring instruments, the use of analytic measures, and the use of methods of extrapolating measures from an experimental setting to a more general and less controlled setting contribute to the overestimation of outcomes. ${ }^{69}$

The tendency to overestimate the benefits and underestimate the risks and costs can also be related to psychological biases, such as "optimism bias" and "planning fallacy,"70 but also to asymmetries in evidence production, such as publication bias. When positive results are more often published than negative results, published (positive) research results are more likely to become false. ${ }^{71}$ Publication bias, which can be rooted in the belief in positive progress and in the desire to capture attention and sell journals, as well as a range of other mechanisms, enhances a quest for positive results, reduces

\footnotetext{
${ }^{66}$ Stegenga, op.cit. note 64.

${ }^{67}$ Lehoux, P., Hivon, M., Williams-Jones, B., Miller, F., \& Urbach, D. (2012). How do medical device manufacturers' websites frame the value of health innovation? An empirical ethics analysis of five Canadian innovations. Medicine, Health Care and Philosophy. 15(1), 61-77.

${ }^{68}$ Stegenga, op.cit. note 64.

${ }^{69}$ Stegenga, op.cit. note 64.

${ }^{70}$ Armor, D. A., \& Taylor, S. E. (1998). Situated optimism: Specific outcome expectancies and self-regulation Advances in experimental social psychology. 30, 309-379; Kahneman, D., \& Tversky, A. (1977). Intuitive prediction: Biases and corrective procedures. Decisions and Designs Inc Mclean Va; Kahneman, D., \& Tversky, A. (1996). On the reality of cognitive illusions. Psychological Review. 103.3: 582.

${ }^{71}$ Dwan, K., Altman, D. G., Arnaiz, J. A., Bloom, J., Chan, A. W., Cronin, E., . . Williamson, P. R. (2008). Systematic review of the empirical evidence of study publication bias and outcome reporting bias. PLoS One. 3(8), e3081. doi:10.1371/journal.pone.0003081; loannidis, J. P. (2007). Why most published research findings are false: author's reply to Goodman and Greenland. PLoS Med. 4(6), e215. doi:10.1371/journal.pmed.0040215; loannidis, J. P. (2008). Why most discovered true associations are inflated. Epidemiology, 19(5), 640-648. doi:10.1097/EDE.0b013e31818131e7
} 
the quality of evidence, and reinforces optimism. These tendencies may be connected to a more general trend of ambivalence to both progress and risk that strongly characterizes modern societies. $^{72}$

Moreover, a "stereotypical master narrative of innovation for growth" (Strand et al., 2016) has also been identified where science and technology "development produces innovations which in turn give rise to economic growth, economic prosperity and the creation of jobs." Corresponding to the SQB and other related mechanisms revealed above, claims about such technological optimism and productivism "are not readily dismissed by their proponents upon exposure to empirical counterevidence." They are viewed as "ideological commitments" and are met with "disagreement also on quality criteria for evidence, incommensurability and partial breakdown of communicative discourse." ${ }^{73}$

Such commitments tend to come out clear in responses to the famous Collingridge dilemma. ${ }^{74}$ As it has become increasingly difficult to predict and control the outcomes of emergent technology, the application of "futuristic visions" of science and technology has increased significantly. ${ }^{75}$ While such visions may be of great importance for debating and assessing technologies, they can also come with a "visionary bias," i.e., the over-optimistic (or over-pessimistic) ideology-driven conception of science and technology, frequently without sufficient acknowledgement of potential harms and implementation costs (or of benefits). Such tendencies and biases may be explained by many psychological mechanisms, such as the "motivated reasoning." ${ }^{76}$ Another explanation could be the general trend to consider it to be better to lead a life that improves than to lead a life that becomes worse with time. ${ }^{77}$

\footnotetext{
${ }^{72}$ Beck, U. (1992). From industrial society to the risk society: questions of survival, social structure and ecological enlightenment. Theory, culture \& society. 9(1), 97-123.

${ }^{73}$ Strand et al., op.cit. note 16.

${ }^{74}$ Collingridge, D. (1982). The social control of technology. New York: St. Martin's Press.

${ }^{75}$ Grunwald, A. (2013). Techno-visionary sciences: challenges to policy advice. Science, Technology \& Innovation Studies. 9(2), 21-38.

${ }^{76}$ Kunda, Z. (1990). The case for motivated reasoning. Psychological bulletin, 108(3), 480.

${ }^{77}$ Velleman, J. D. (1991). Well-Being and Time. Pacific Philosophical Quarterly. 72(1), 48-77.
} 
The identity-preserving mechanisms described above to potentially support SQB appear to be as relevant in technology optimism. As some people's identity is constituted by the prevailing, other is reinforced by the new. As put by the medieval historian Lynn White: "People are organized into cultures by the basic presuppositions - often unverbalized - that they share: their axioms."${ }^{178}$ Conceptions of progress, novelty, and change may create culturally contingent biases in the same way as with SQB. This is also supported by a historical view on the conception of technology: "The Latin Middle Ages, by contrast [to the pagan and Christian antiquity], developed an almost entirely affirmative view of technological improvement. This new attitude is clearly detectable in the early ninth century, and by 1450 engineering advance had become explicitly connected with the virtues: it was integral to the ethos of the West." ${ }^{179}$ White makes an important and still valid observation when he claims that we tend to believe that "all problems produced by changing engineering will be solved automatically by remedial forms of technology, quite without the intrusion of public policy based on ethical and esthetic sensibility." ${ }^{80}$ The "technological fix" tends to provide a cognitive bias as does SQB, however with opposite sign.

One important implication of positive attitudes towards emerging technologies may be called primacy bias, i.e., the effect that whenever a technology has been invented or introduced, it is almost impossible to re-assess, de-invent, dispose, de-adopt, or dis-invest. ${ }^{81}$ Technology introduction tend to frame and bind its applications, i.e., beginnings count. ${ }^{82}$ The tendency that when technologies have been invented and implemented, it is very hard to discard or disinvest such

\footnotetext{
${ }^{78}$ White, L. (1974). Technology assessment from the stance of a medieval historian. Technological forecasting and social change. 6, 359-369.

${ }^{79}$ White, op.cit. note 78 .

${ }^{80}$ White, op.cit. note 78.

${ }^{81}$ Haas, M., Hall, J., Viney, R., \& Gallego, G. (2012). Breaking up is hard to do: why disinvestment in medical technology is harder than investment. Aust Health Rev. 36(2), 148-152. doi:10.1071/ah11032; Henshall, C., Schuller, T., \& Mardhani-Bayne, L. (2012). Using health technology assessment to support optimal use of technologies in current practice: the challenge of "disinvestment". Int J Technol Assess Health Care. 28(3), 203210. doi:10.1017/s0266462312000372; Niven, D. J., Mrklas, K. J., Holodinsky, J. K., Straus, S. E., Hemmelgarn, B. R., Jeffs, L. P., \& Stelfox, H. T. (2015). Towards understanding the de-adoption of low-value clinical practices: a scoping review. BMC Med. 13(1), 255; Prasad, V., \& loannidis, J. P. (2014). Evidence-based de-implementation for contradicted, unproven, and aspiring healthcare practices. Implement Sci. 9, 1. doi:10.1186/1748-5908-9-1.

${ }^{82}$ Rothman, D. (1997). Beginnings count: the technological imperative in American health care. New York: Oxford University Press.
} 
technologies has been interpreted as a kind of inertia. Disinvestment in health care may serve as an example, where technologies are applied even if it is well known that they have little or no effect (and even if they are harmful). ${ }^{83}$ In the USA alone approximately $\$ 200$ billion is spent on healthcare services that provide little value to patients every year. Even after information about the low value of specific technologies, they are still widely applied. ${ }^{84}$ For example, there has been a very low and slow decrease in low-value back imaging despite long standing evidence of poor effect. ${ }^{85}$

Another important driver of modern technology, is its symbolic value. ${ }^{86}$ When assessing technology the "extravagance and status symbol" as well as "the nonquantifiable values of vanity and political visibility" tend to play a major role, although vastly ignored. ${ }^{87}$ Clearly, such symbolic value will spur optimism and non-warranted implementation.

In a seminal article, Eric Cassell explains the urge to implement science and technology (in health care) in terms of three feedback loops. First, "[s]cience increases knowledge of the disease by employing technologies and promoting the development of further technologies."(p.33). Second, technology holds and enhances the power of the users, and third, technology directs medicine's focus on disease and pathophysiology enhancing the development and application of medical technology ${ }^{88}$ Cassell explains the prominence and position of these self-perpetuating aspects of science and technology in terms of five human characteristics (in terms of deficiencies): human beings have a tendency to wonder (in order to reduce boredom and create meaning), are attracted to the immediate (due to a fundamental dislike of reason), are afraid of and tend to reduce ambiguity (because ambiguity is threatening the consistency of a persn's worldview), dislike uncertainty, and

\footnotetext{
${ }^{83}$ Fisher, E. S., \& Welch, H. G. (1999). Avoiding the unintended consequences of growth in medical care: how might more be worse? JAMA. 281(5), 446-453.

${ }^{84}$ Rosenberg, A., Agiro, A., Gottlieb, M., Barron, J., Brady, P., Liu, Y., . . . DeVries, A. (2015). Early Trends Among Seven Recommendations From the Choosing Wisely Campaign. JAMA Intern Med. 175(12), 1913-1920. doi:10.1001/jamainternmed.2015.5441.

${ }^{85}$ Mafi, J. N., Russell, K., Bortz, B. A., Dachary, M., Hazel, W. A., Jr., \& Fendrick, A. M. (2017). Low-Cost, HighVolume Health Services Contribute The Most To Unnecessary Health Spending. Health Aff (Millwood), 36(10), 1701-1704. doi:10.1377/hlthaff.2017.0385.

${ }^{86}$ Hofmann, B. (2015). Too much technology. BMJ. 350. doi:http://dx.doi.org10.1136/bmj.h705.

${ }^{87}$ White, op.cit. note 78.

${ }^{88}$ Cassell, E. (1993). The Sourcer's Broom. Medicine's Rampant Technology. Hastings Center Report. 23(6), 32-
} 39. 
have a strong desire for power. (p33). These characteristics work as psychological or behavioral mechanisms promoting science and technology optimism.

Another explanation of the strong and frequently biased drive for technology is what has been called the technological imperative. ${ }^{89}$ This imperative can have many explanations and mechanisms, such as anticipated decision regret, ${ }^{90}$ imperative of action ("spontaneous urge to action"), ${ }^{91}$ the imperative of possibility ("can do, must do"), the imperative resulting from means becoming ends, ${ }^{92}$ and the imperative of quantity ("more is better than less"). ${ }^{93}$ The technological imperative has been explained in many ways, e.g., as autonomous technology, ${ }^{94}$ as technological determinism, ${ }^{95}$ or in terms of human deficiencies. ${ }^{96}$ On a related, but somewhat different, note our tendencies towards implementing technologies have also been studied and explained as "technological affordances", ${ }^{97}$ in terms of a range of specific drivers, ${ }^{98}$ and because of its mythical status. ${ }^{99}$ The point here is not to enter the old and still open debate on determinism or the detailed discussions of various mechanisms, but rather to point out that the technological imperative can be one expression of a positive bias to technology opposing to SQB.

\footnotetext{
${ }^{89}$ Barger-Lux, M. J., \& Heaney, R. P. (1986). For better and worse: the technological imperative in health care. Soc Sci Med. 22(12), 1313-1320; Gillick, M. R. (2007). The technological imperative and the battle for the hearts of America. Perspect Biol Med. 50(2), 276-294. doi:10.1353/pbm.2007.0017; Jennett, B. (1994). Medical technology, social and health care issues. In R. Gillon (Ed.), Principles of health care ethics (pp. 861-872). New York: Wiley; Mandell, H. N. (1983). Technological imperative. Or, when your tool is a hammer, everything looks like a nail. Postgrad Med, 74(2), 24-26; Wolf, S., \& Berle, B. (1981). The Technological Imperative in Medicine. New York: Plenum Press; Rothman, op.cit. note 82.

${ }^{90}$ Tymstra, T. (1989). The imperative character of medical technology and the meaning of "anticipated decision regret". Int J of Technology Assessment in health Care, 5, 207-213.

${ }^{91}$ Kyenes, op.cit. note 57.

92 Hofmann, B. (2002). The myth of technology in health care. Sci Eng Ethics. 8(1), 17-29.

${ }^{93}$ Fisher, E. S. (2003). Medical care--is more always better? New England Journal of Medicine. 349(17), 16651667.

${ }^{94}$ Ellul, J. (1964). The Technological Society. New York: Alfred A. Knopf; Winner, L. (1977). Autonomous Technology. Cambridge Ma: MIT Press.

${ }^{95}$ Marx, op.cit. note 8.

${ }^{96}$ Cassell, op.cit. note 88.

${ }^{97}$ Borup, M., Brown, N., Konrad, K., \& Van Lente, H. (2006). The sociology of expectations in science and technology. Technology analysis \& strategic management. 18(3-4), 285-298; Gaver, W. W. (1991). Technology affordances. Proceedings of the SIGCHI conference on Human factors in computing systems. Acm; Webster, A. (2007). Health Technology and Society: a Sociological Critique. New York: Palgrave Macmillan Publication. ${ }^{98}$ Hofmann, op.cit. note 86 .

${ }^{99}$ Hofmann, B. (2002). Is there a technological imperative in health care? Int J Technol Assess Health Care. $18(3), 675-689$
} 
In this section I have tried to illustrate that there are other biases and mechanisms at play in the assessment and implementation of emerging science and technology. Figure 2 gives an overview of relevant biases and corresponding mechanisms that drive optimism. The table is by no means exhaustive.

Figure 2 Overview of biases and mechanisms that drive science and technology optimism

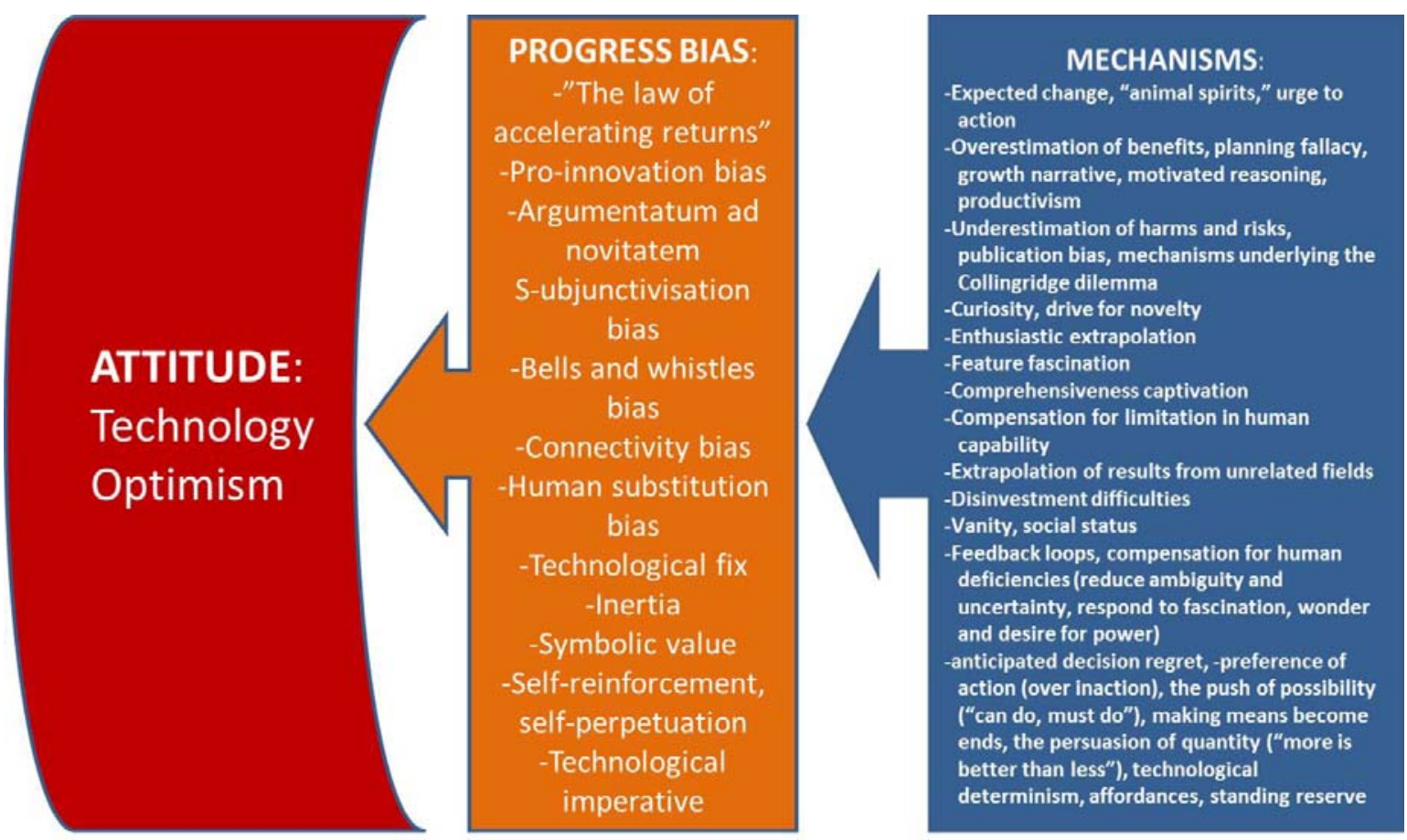

Although many of the examples are from the implementation and use of technology in health care, it appears relevant also for the enhancement and the general science and technology debate. If "The Mug Experiment," "Hypothetical Choice Tasks," and the "Electric Power Consumers" experiment that Bostrom and Ord use as the proof of SQB are relevant for the debate on human enhancement technologies, the cases and examples of mechanisms and biases from the implementation and use of technology in health care are at least as relevant.

Again, the point has not been to give a comprehensive, exhaustive or systematic overview of all relevant mechanisms and biases driving science and technology optimism. That would be beyond the 
scope of this article. Rather the point is to illustrate that SQB is only one amongst many other relevant biases, and that it may even not be the most important one. When assessing the SQB in the debate on emerging technologies, we need to acknowledge its context.

\section{The progress bias}

The identified biases seem quite diverse, and are driven by miscellaneous underlying mechanisms.

What is common, however, is that they tend to have an irrational or unsubstantiated preference for science and technology. In the following, I will call this bias progress bias (PB). A specific kind of PB is the direct opposite of $\mathrm{SQB}$, i.e., $\mathrm{PB}_{\mathrm{SQB}}$ is an irrational preference for an option only because it potentially alters the current state of affairs. As SQB, PB is a type of cognitive (attitude) bias. Examples of progress bias (beyond what have been provided above) can be seen in other fields, such as cancer drugs which are approved and implemented long before any evidence on survival and quality of life are available. ${ }^{100}$

The main challenge with PB is that it makes us a) ignore important facts and values for decision making, b) it distorts or frames the decision-making process (and thereby violates principles for democratic deliberation), c) it makes us ignore epistemic shortcomings in that we ignore our ignorance, and d) may have significant consequences for individuals and populations. The unintended consequences can in principle be good and bad, reversible and irreversible, and related to facts, norms, and values. Hence, it is of utmost importance for ethics, and specifically the ethics of emergent technologies. Even if the implications of PB can be positive (in d), the implications of a-c) would justify caution against PB.

In the same manner as Bostrom and Ord argue for tests for avoiding SQB, we should therefore have tests to check for PB in order to make more sound assessments of emerging technologies, e.g., human enhancement technologies.

\footnotetext{
${ }^{100}$ Davis, C., Naci, H., Gurpinar, E., Poplavska, E., Pinto, A., \& Aggarwal, A. (2017). Availability of evidence of benefits on overall survival and quality of life of cancer drugs approved by European Medicines Agency: retrospective cohort study of drug approvals 2009-13. BMJ. 359. doi:10.1136/bmj.j4530
} 


\begin{tabular}{|c|c|c|}
\hline & TEST & Comment / example \\
\hline 1 & $\begin{array}{l}\text { Distinguishing principled from real arguments: When you } \\
\text { argue for the research or implementation of a specific science } \\
\text { or technology from the premise of perfect outcome and } \\
\text { guaranteed safety, then you need to explain why this argument } \\
\text { has any bearing for real world research or implementation. }\end{array}$ & $\begin{array}{l}\text { Watch for premises like "safe, } \\
\text { effective, and affordable"101 } \\
\text { and question how they know } \\
\text { and how you can find out. }\end{array}$ \\
\hline 2 & $\begin{array}{l}\text { Uncertain premises (changing outcome and its value): When } \\
\text { you argue for the research or implementation of a specific } \\
\text { science or technology because it is thought to have good } \\
\text { overall consequences, but you do not provide evidence of the } \\
\text { outcome or how it will change the value of or evaluation of the } \\
\text { outcome, then you need to explain why the research or } \\
\text { implementation of this science or technology will have the } \\
\text { suggested outcome. }\end{array}$ & $\begin{array}{l}\text { Watch for assurances of overall } \\
\text { net benefits where no or poor } \\
\text { quality evidence is provided. } \\
\text { Also ask how the science and } \\
\text { technology may alter the } \\
\text { evaluation as such. }\end{array}$ \\
\hline 3 & $\begin{array}{l}\text { Solving, not producing problems: When you think that any of } \\
\text { the problems that you acknowledge should be solved by } \\
\text { progress in field } X \text {, you need to make sure that these problems } \\
\text { are not the result of progress in this field or of other } \\
\text { corresponding progress. If the problems have been created by } \\
\text { previous progress in field } X \text { or in other fields, or may increase } \\
\text { following from the progress you are instigating, then you need } \\
\text { to explain why further progress in } X \text { will reduce and not } \\
\text { increase the problems. }\end{array}$ & $\begin{array}{l}\text { Be alert to unsubstantiated } \\
\text { claims that science and } \\
\text { technology will solve problems } \\
\text { generated by science and } \\
\text { technology and that future } \\
\text { problems stemming from the } \\
\text { sciences and technologies at } \\
\text { debate will be solved by even } \\
\text { more advanced science and } \\
\text { technology in the future. }\end{array}$ \\
\hline 4 & $\begin{array}{l}\text { (De)implementation symmetry: When an emerging } \\
\text { technology is suggested to be implemented, what are the } \\
\text { criteria for de-implementing or disinvesting in that technology? } \\
\text { If these criteria have not been applied to deimplement } \\
\text { technologies of low, no, or negative value, then you need to } \\
\text { explain to what extent your de-imlementation criteria are } \\
\text { relevant. }\end{array}$ & $\begin{array}{l}\text { If you want to introduce } \\
\text { emerging technologies believed } \\
\text { to be of great value in areas } \\
\text { where technologies of low, } \\
\text { negative, or no value are in } \\
\text { widespread use and not } \\
\text { removed, ask if you have } \\
\text { assessed the new technology } \\
\text { well enough. }\end{array}$ \\
\hline 5 & $\begin{array}{l}\text { "REVERSAL TEST" for PB: Suppose it is thought that increasing } \\
\text { a certain parameter would have good overall consequence. } \\
\text { Consider a scenario in which a natural factor or the very } \\
\text { increase of the parameter itself threatens to change the value } \\
\text { of this consequence in a negative direction. If you still think it is } \\
\text { good to increase the parameter, then you need to explain why } \\
\text { our position is such that it can be improved through changes to } \\
\text { this parameter. }\end{array}$ & $\begin{array}{l}\text { Example: If you use science or } \\
\text { technology to increase a } \\
\text { human characteristic (e.g., } \\
\text { human intelligence because } \\
\text { "intelligence is beneficial on } \\
\text { virtually any theory of } \\
\text { benefit"102), but it actually } \\
\text { decreases the overall benefit or } \\
\text { changes the evaluation, would } \\
\text { you then be willing to reverse } \\
\text { the process? }\end{array}$ \\
\hline 6 & $\begin{array}{l}\text { DOUBLE REVERSAL TEST for PB: Suppose it is thought that } \\
\text { increasing a certain parameter would have good overall } \\
\text { consequences and decreasing it would both have bad overall }\end{array}$ & $\begin{array}{l}\text { Example: If the general } \\
\text { intelligence is decreased (e.g., } \\
\text { due to radiation exposure) but }\end{array}$ \\
\hline
\end{tabular}

${ }^{101}$ Bostrom \& Ord, op.cit. note 26.

102 Moen OM. (2016). Bright new world. Cambridge Quarterly of Healthcare Ethics 25(2): 282-287. 


\begin{tabular}{|c|c|c|}
\hline & $\begin{array}{l}\text { consequences. Consider a scenario in which a natural factor } \\
\text { decreases the parameter but showing increased benefit. Would } \\
\text { you then consider it to be good to counterbalance this change } \\
\text { by increasing the parameter? If not, consider a later time when } \\
\text { the natural factor is about to vanish (and thereby increasing } \\
\text { the parameter back to normal) and ask whether it would be a } \\
\text { good idea to decrease the parameter. If not, then there is a } \\
\text { strong prima facie case for thinking that it would be bad to } \\
\text { make the first intervention even in the absence of the natural } \\
\text { factor. }\end{array}$ & $\begin{array}{l}\text { you find out that this increases } \\
\text { the general benefit, would you } \\
\text { then try to increase it (back to } \\
\text { original)? If not, what would } \\
\text { you do after the exposure } \\
\text { vanishes, and the general } \\
\text { intelligence increases again } \\
\text { (back to the original) reducing } \\
\text { the general benefit. Would you } \\
\text { then intervene to decrease } \\
\text { intelligence? }\end{array}$ \\
\hline 7 & $\begin{array}{l}\text { Identifying biases: Can you in your argument for or against } \\
\text { certain developments in science or technology identify any of } \\
\text { the biases or mechanisms in Figure } 1 \text { or } 2 \text { ? if so, then revise } \\
\text { your argument. }\end{array}$ & See Figure 1 and 2. \\
\hline
\end{tabular}

1.

\section{Discussion}

In this article I have addressed the question of whether we behave rationally with respect to assessing science and technology. General attitudes, such as pessimism and optimism, appear to be driven by cognitive or attitudinal biases and distort our conceptions and assessments. I have taken the SQB as a point of departure and used human enhancement as an example. The analysis shows that there is little evidence that the endowment effect plays any particular role in the reasoning on biotechnology in general or on enhancement technologies in particular. Moreover, I have found that the SQB may be driven by other mechanisms than the endowment effect and that it may be opposed by a range of other pervasive biases driving the arguments in the opposite (optimistic) direction. The complaint about a "status quo bias"103 has to be set in context of an opposing "progress bias." Accordingly, the above questions may serve as tests to halt biased assessments and unwarranted arguments.

\footnotetext{
${ }^{103}$ Bostrom \& Ord, op.cit. note 26.
} 
We need to take these tendencies seriously, especially as ethics seems to go along with the hypes and hopes of science and emerging technologies far too easily. ${ }^{104}$ We tend to ignore the high level of uncertainties about scientific progress and may not be willing to alter our beliefs or claims on the basis of new evidence. Moreover, scientific hype is a substantial moral and political problem because it can undermine the overall credibility of science among the public. ${ }^{105}$ Unfortunately, Clarke's Third Law still seems relevant: "Any sufficiently advanced technology is indistinguishable from magic."106 Ethicists appear to be as much subject to emotional and cognitive biases in discussions on science and technology as others. Therefore, we need to remind ourselves of the teachings of Leonardo da Vinci and "demystify" not only our notions of nature, but also our conceptions of science and technology. ${ }^{107}$ Hence, ethicists should elaborate measures to identify and defuse biases in ourselves and others. We should become "bias busters." One way to do so it by elaborating quality criteria for ethical analysis. ${ }^{108}$ The tests suggested here may be another.

As already indicated, the study of the aspects and mechanisms of progress bias are by no means exhaustive. There are many other biases relevant to deliberation on science and technology as well. For instance, a wide range of framing effects are relevant and interesting. ${ }^{109}$ The point here has merely been that SQB is by far the only bias, and that it has to been assessed against a range of other biases. These biases are part of a mere overall tendency of strong and polarized opinions about science and technology; either optimistic or pessimistic. My analysis indicates that pessimism may not be the only or prevailing attitude neither in emergent technologies in general nor in human enhancement in particular.

\footnotetext{
${ }^{104}$ Lucivero, F., \& Vedder, A. (2013). Beyond therapy v. enhancement?: multidisciplinary analyses of heated debate. Pisa: Pisa University Press; Nordmann, A., \& Rip, A. (2009). Mind the gap revisited. Nature nanotechnology. 4(5), 273; Vedder, A. H. (2013). Human enhancement on the slab. In F. Lucivero \& A. H. Vedder (Eds.), RoboLaw Series: Pisa University Press.

${ }^{105}$ Caulfield, op.cit. note 10.

${ }^{106}$ Clarke, A. C. (1962). Hazards of Prophecy: The Failure of Imagination. Profiles of the Future. 6, 36.

107 Hofmann, op.cit. note 92.

${ }^{108}$ Hofmann, B., \& Magelssen, M. (2018). In pursuit of goodness in bioethics: analysis of an exemplary article. BMC Med Ethics. 19(1), 60.

${ }^{109}$ Levin, I. P., Schneider, S. L., \& Gaeth, G. J. (1998). All frames are not created equal: A typology and critical analysis of framing effects. Organizational behavior and human decision processes. 76(2), 149-188.
} 
Moreover, I have not been very strict on what counts as a bias. There are of course significant differences between the endowment effect (rooted in Prospect Theory) and identity-protective cognition. Additionally, context may modify the effects of the various biases. ${ }^{110}$ The difference between attitudes (to science and technology), biases, and mechanisms and the detailed relationship between them deserves much more attention than possible in the scope of this article. My point here has not been to enter the detailed debates on the various types of propensities resulting in polarized (and irrational) attitudes to emerging technologies, or in the detailed relationship between attitudes, biases, and mechanisms, but rather to explore and display the interplay more broadly. While a fine-grained taxonomy is interesting, it is not necessary for my main argument. In the same manner as SQB is not only relevant for human enhancement, as discussed by Bostrom and Ord, neither is PB. However, as human enhancement was the context of their argument, their example has been the main focus of this article as well. Although PB has not been elaborated for science and technology in general, and has to be analyzed in detail for this broader context, there are reasons to believe that PB is relevant for a broader range of sciences and technologies. One reason is that many of the examples of various types of progress bias are not limited to human enhancement or health technologies.

On the other hand, it may be argued that we have little evidence and experience about human enhancement technologies yet, and that the discussion of the biases and its mechanisms are not relevant for enhancement technologies. However, a debate about the attitudes and arguments with respect to science and technology does not depend on the outcome of the implementation of this technology but on how the reasoning and deliberation goes. Moreover, if PB is relevant for a wide range of other technologies, there is a good chance that it can occur in the assessment and implementation of technologies in the field of human enhancement as well.

\footnotetext{
${ }^{110}$ Druckman, J. N. (2004). Political preference formation: Competition, deliberation, and the (ir) relevance of framing effects. American Political Science Review. 98(4), 671-686.
} 
I may also rightly be criticized for applying mechanisms and biases from the assessment and implementation of health technologies to the field of human enhancement. However, this seems justified as long as many of the technologies envisioned for enhancement are also used (therapeutically) in health care. ${ }^{111}$

Additionally, I can be criticized for being too binary, only distinguishing between optimism and pessimism. One can argue that SQB is related more to skepticism than to pessimism or that the opposite camp of those affected by SQB is not the optimists. I could agree to several of these objections, as there are many ways to categorize the proponents and opponents of science and technology in general and human enhancement in particular. ${ }^{112}$ Here I have only used optimists versus pessimists as terms to illustrate the overall polarization in the field.

It can also be argued that optimists and pessimist (or proponents and critics of human enhancement) share the same moral ideal (authenticity) and that ambivalence with respect to the positions is preferable. ${ }^{113}$ Correspondingly, one may argue that PB and SQB represent the same ambivalence or that they will even each other out, resulting in balanced assessments, or that we need to balance assessment and decision-making bodies with optimistic and pessimistic members. However, both biases are irrational elements, and it may be argued that should be avoided in rational, open and transparent decision making as much as possible.

It may also be maintained that PB is not prevalent or important, and that it is a rare and isolated phenomenon. However, PB can be connected to a more general and irrational optimism where

\footnotetext{
${ }^{111}$ Chan, S., \& Harris, J. (2006). Cognitive regeneration or enhancement: the ethical issues. Regen Med. 1(3), 361-366. doi:10.2217/17460751.1.3.361; Daniels, N. (2000). Normal functioning and the treatmentenhancement distinction. Cambridge Quarterly of Healthcare Ethics. 9(03), 309-322; Huggins, J., \& Simmerling, M. (2014). Normal Functioning and the Treatment/Enhancement Distinction: An Opportunity Based Assessment. Journal of religion and health. 53(4), 1214-1222; Maslen, H., Earp, B. D., Cohen Kadosh, R., \& Savulescu, J. (2014). Brain stimulation for treatment and enhancement in children: an ethical analysis. Front Hum Neurosci. 8, 953. doi:10.3389/fnhum.2014.00953.

${ }_{112}$ Giubilini, A., \& Sanyal, S. (2015). The ethics of human enhancement. Philosophy Compass. 10(4), 233-243.

${ }^{113}$ Parens, E. (2005). Authenticity and ambivalence: toward understanding the enhancement debate. Hastings Center Report. 35(3), 34-41.
} 
people think they are better drivers, teachers, and lovers than the average ${ }^{114}$ that nothing bad will happen to them, ${ }^{115}$ and how such types of irrational optimism ${ }^{116}$ plays out in economics dominated by "optimism-fueled financial speculations". ${ }^{117}$ In specific fields one has even made up diagnoses for this optimism, such as "HITIOS: Health Information Technologist Irrational Optimism Syndrome."118

In the same way that "Medieval Europe came to believe that technological progress was part of God's will for man"119 it seems that we today believe that we are to use technology to guide or improve evolution. Man has apparently become the measure of everything (homo mensura) and progress of science and technology is part of our eidos.

\section{Conclusion}

No doubt, Bostrom and Ord may have a point when they claim that crucial progress in science and technology is fettered by an irrational status quo bias (SQB). However, the analysis of SQB reveals that this at best is one amongst many drivers of attitudes to emergent technologies, such as human enhancement. It does not seem to be as prominent as suggested in the literature, and its mechanisms appear to be more diverse than previously acknowledged. While recognizing that SQB may be one driver behind science and technology pessimism, I have identified a wide range of other drivers and mechanisms which may be as forceful as SQB, and which work in the opposite direction. "Progress bias" is suggested as a generic term for the various forces driving unwarranted science and technology optimism. Based on the analysis I have developed a test for revealing, avoiding, or

\footnotetext{
${ }^{114}$ Thaler, R. H., \& Sunstein, C. R. (2008). Nudge: Improving decisions about health, wealth, and happiness. New Haven: Yale University Press.

${ }^{115}$ Weinstein, N. D. (1980). Unrealistic optimism about future life events. Journal of personality and social psychology. 39(5), 806.

${ }^{116}$ Dimson, E., Marsh, P., \& Staunton, M. (2004). Irrational optimism. Financial Analysts Journal. 60(1), $15-25$.

${ }^{117}$ Stout, L. A. (2011). Uncertainty, dangerous optimism, and speculation: An inquiry into some limits of democratic governance. Cornell L Rev. 97, 1177.

${ }^{118}$ Newbell, B. J. (2013). HITIOS: Why Cynicism Is Helpful When Working With Health IT. Family practice management. 20(4), 40-40.

${ }^{119}$ White, op.cit. note 78.
} 
reducing this progress bias. When assessing attitudes driving irrational or unreasoned assessments of technology we should focus on a broader range of drivers than only single biases, such as SQB.

Focusing only on SQB in the assessment of novel technologies can in itself be interpreted as a PB.

Science and technology are of utmost importance for individuals, societies, as well as globally. To assess and implement them in a balanced and reasoned way is a major task for ethics. Hence, we need to uncover and undermine biases in order to obtain open, transparent and sound deliberations on advances in science and technology. 